\title{
HUBUNGAN KERJASAMA, MOTIVASI, SIKAP, DAN KINERJA BIDAN DALAM PELAYANAN ANTENATAL
}

\section{CORRELATION OF MIDWIFE'S COOPERATION, MOTIVATION, ATTITUDE AND PERFORMANCE ON} ANTENATAL CARE

\section{Achmad Djunawan, Setya Haksama}

Fakultas Kesehatan Masyarakat, Universitas Airlangga, Surabaya E-mail: achmadjuna@gmail.com

\begin{abstract}
Antenatal care in last three years at Kecamatan Kejayan did not reach the target, $100 \%$ for K1 and 95\% for K4. This research aims to analyze the correlation of midwife's cooperation, motivation, attitude, and performance on antenatal care in non insurance and insurance patients group. This is a quantitative research with cross sectional design. Spearman Correlation and Coeficient Contingency were used in this research to analyze the data. 36 midwifes were interviewed to obtain data.The results show that majority midwifes has cooperation with primary health care. Midwife's motivation was high and attitude was positive. Midwife's performance to non insurance and insurance patients was very high. There was moderate correlation $(r=0,446)$ between cooperation (midwife with primary health care) and the performance to non insurance patients. There was very weak correlation $(r=0,111)$ between cooperation (mindwife with doctor) and performance to insurance patients, and weak correlation $(r=0,311)$ to non insurance patients. There was weak correlation $(r=0,086)$ between motivation and performance to insurance patients, whereas correlation to non insurance was moderate $(r=0,521)$. There was strong correlation $(r=0,707)$ between attitude and performance to non insurance patient. The conclusion, attitude has most significant with performance in non insurance patient group.
\end{abstract}

Keywords: antenatal care, attitude, cooperation, motivation, performance

\section{PENDAHULUAN}

Pemerintah merupakan organisasi yang bertanggung jawab menyelenggarakan pelayanan kesehatan yang menyeluruh, bermutu dan terjangkau untuk semua lapisan masyarakat, baik pelayanan promotif, preventif, kuratif, maupun rehabilitatif. Pada tahun 2014 pemerintah telah menetapkan peraturan tentang Jaminan Kesehatan Nasional (JKN) yang pelayanannya mengikuti sistem rujukan berjenjang sesuai kebutuhan (Permenkes, 2013). Badan Penyelenggara Jaminan Sosial (BPJS) Kesehatan merupakan badan hukum yang dibentuk untuk menyelenggarakan JKN dan bertanggung jawab langsung kepada presiden (Perpres, 2013).

Terdapat target untuk menyelesaikan permasalahan kesehatan terutama terkait dengan kesehatan ibu dan alnak dalam Millenium Development Goals (MDG's). Salah satu target
MDG's adalah mengurangi tiga per empat rasio kematian ibu dalam proses melahirkan dalam kurun waktu 1990-2015. Target penurunan angka kematian ibu (AKI) di Indonesia pada tahun 2015 adalah 102 kematian per 100.000 kelahiran hidup (Depkes RI, 2009).

Angka Kematian Ibu (AKI) di Kabupaten Pasuruan adalah 92 kematian per 100.000 kelahiran hidup pada tahun 2011, 112 kematian per 100.000 kelahiran hidup pada tahun 2012 dan 2013. Kecamatan yang mengalami peningkatan kasus kematian ibu adalah Kecamatan Kejayan. AKI di Kecamatan Kejayan sebesar 0 kematian per 100.000 kelahiran hidup pada tahun 2011, 107 kematian per 100.000 kelahiran hidup pada tahun 2012, dan 310 kematian per 100.000 kelahiran hidup. Selain meningkatnya kasus kematian ibu di Kecamatan Kejayan, AKI di Kecamatan Kejayan pada tahun 2012 dan 2013 tidak mencapai target 
MDG's yang sebesar 102 kematian per 100.000 kelahiran hidup (Dinkes Pasuruan, 2014).

Kunjungan pertama ibu hamil (K1) di Puskesmas Kejayan selama tahun 2011 sampai tahun 2013 tidak memenuhi target yang sebesar $100 \%$. Kunjungan keempat ibu hamil (K4) di Puskesmas Kejayan selama tahun 2011 sampai tahun 2013 tidak memenuhi target yang sebesar 95\%. K4 di Puskesmas Ambal ambil mengalami penurunan selama tahun 2011 sampai tahun 2013. K1 merupakan salah satu indikator cakupan pelayanan antenatal dan K4 merupakan salah satu indikator kualitas pelayanan antenatal (Dinkes, 2014).

Masalah dalam penelitian ini adalah meningkatnya angka kematian ibu di Kecamatan Kejayan Kabupaten Pasuruan. Penelitian ini bertujuan untuk menganalisis hubungan kerjasama, motivasi dan sikap dengan kinerja bidan dalam pemberian pelayanan antenatal pada pasien peserta BPJS dan pasien umum di Kecamatan Kejayan Kabupaten Pasuruan. Penelitian ini dapat digunakan sebagai tambahan pustaka serta dapat digunakan sebagai pertimbangan dalam mengambil kebijakan tentang pelayanan antenatal.

\section{PUSTAKA}

Kinerja (performance) disebut juga dengan prestasi kerja. Menurut As'ad (2003) kinerja (job performance) adalah hasil yang dicapai oleh seseorang menurut ukuran yang berlaku untuk pekerjaan yang bersangkutan. Ilyas (2001) menjelaskan bahwa kinerja adalah penampilan hasil karya personil baik kualitas maupun kuantitas dalam suatu organisasi. Kinerja merupakan suatu gambaran mengenai tingkat pencapaian pelaksanaan suatu kegiatan, program atau pelaksanaan kebijakan dalam mewujudkan sasaran, tujuan, misi, dan visi. Pengertian kinerja berkaitan dengan tanggung jawab individu, kelompok, atau organisasi dalam menjalankan apa yang menjadi wewenang dan tanggung jawab yang telah diberikan.

Variabel yang mempengaruhi kinerja adalah kemampuan, keterampilan, persepsi, sikap, kepribadian, motivasi, pembelajaran, stress, imbalan, sumber daya, desain pekerjaan, kepemimpinan, dan struktur organisasi. Variabel dibagi dalam tiga kategori yaitu fisiologis, psikologis, dan lingkungan (organisasi). Variabel fisiologis terdiri atas kemampuan dan keterampilan. Variabel psikologis terdiri atas persepsi, sikap, kepribadian, motivasi, pembelajaran, dan stress. Variabel lingkungan (organisasi) terdiri atas imbalan, sumber daya, desain pekerjaan, kepemimpinan, dan struktur organisasi (Gibson, et al, 1989).

Kerjasama membahas hubungan antara 2 orang atau organisasi. Kerjasama sendiri adalah penggabungan aktivitas antara 2 orang atau organisasi untuk mencapai tujuan yang mungkin sulit dicapai dan memakan biaya besar bila dilakukan sendirian. Setiap orang atau organisasi yang terikat dalam kerjasama harus percaya bahawa rekannya akan mencapai tujuan tersebut (Brito, et al, 2014).

Bidan dapat memberikan pelayanan kebidanan pada pasien BPJS apabila telah bekerjasama dengan BPJS secara langsung atau 
melalui Penyelenggara Pelayanan Kesehatan Tingkat Pertama (PPK I) (Permenkes, 2013).

Motivasi adalah konsep kekuatan didalam diri seseorang yang dapat mengarahkan perilaku orang tersebut. Kebutuhan merupakan penggerak atau pembangkit perilaku. Kebutuhan dapat merupakan kekurangan yang dirasakan pada waktu tertentu. Terdapat lima tingkat kebutuhan menurut maslow yaitu kebutuhan jasmani, kebutuhan rasa aman, kebutuhan sosial, kebutuhan penghargaan, dan kebutuhan aktualisasi diri (Gibson, et al, 1989).

Sikap adalah kesiagaan mental yang dapat dipelajari dan diorganisasi dari pengalaman dan mempunyai pengaruh atas cara tanggap terhadap orang lain, obyek dan situasi yang berhubungan dengannya (Gibson, et al, 1989).

\section{METODE}

Jenis penelitian ini merupakan penelitian kuantitatif dengan rancang bangun cross sectional study. Pendekatan yang digunakan adalah observasional dan bersifat deskriptif. Waktu penelitian dilaksanakan pada bulan Agustus-Oktober 2014. Lokasi penelitian ini adalah Kecamatan Kejayan Kabupaten Pasuruan. Populasi dalam penilitian ini 36 bidan dengan kriteria inklusi aktif melakukan praktik kebidanan di Kecamatan Kejayan dan menandatangani informed consent. Terdapat 27 bidan yang memberikan pelayanan pada pasien BPJS. Penelitian ini menggunakan total sampling karena jumlah responden relatif sedikit. Variabel yang dalam penelitian ini adalah kinerja bidan dalam pelayanan antenatal pada pasien BPJS dan pasien umum sebagai variabel dependen sedangkan kerjasama, motivasi, sikap sebagai variabel independen.

Penelitian ini diawali dengan pelaksanaan uji etik. Setelah itu, lalu dilanjutkan dengan melakukan uji validitas reabilitas. Pertanyaan yang tidak reliabel dan tidak valid dieliminasi. Data penelitian tentang kerjasama, motivasi, sikap, dan kinerja diperoleh dengan melakukan wawancara dengan panduan wawancara kepada bidan yang melakukan praktik kebidanan di wilayah Kecamatan Kejayan Kabupaten Pasuruan.

Penilaian variabel kerjasama berdasarkan perjanjian kerjasama yang telah dibuat antara bidan dengan BPJS, PPK I, dan dokter pembina (dalam satu wilayah Kecamatan Kejayan). Penilaian motivasi berdasarkan faktor yang mendorong bidan untuk kerjasama dengan BPJS, PPK I (puskesmas, klinik pratama, dokter praktik) dan dokter pembina terdiri atas pendapatan tambahan, alur administrasi, prosedur kerjasama, kecepatan pelayanan kerjasama, persyaratan kerjasama, besaran kapitasi, pelaporan, tantangan, pengembangan karir, dan tanggung jawab profesi. Sikap merupakan perasaan atau respon bidan untuk setuju atau tidak dalam bekerjasama dengan BPJS, PPK I (puskesmas, klinik pratama, dokter praktik), dan dokter pembina. Kinerja merupakan hasil kerja bidan dalam pelayanan antental meliputi prosedur administrasi, anamnesa, pemeriksaan fisik, pemeriksaan kebidanan, penyuluhan, rujukan ibu hamil resiko tinggi, hubungan dengan ibu hamil, keamanan dan kenyamanan. Setelah data didapatkan dilanjutkan dengan mengidentifikasi distribusi setiap variabel dan menganalisis hubungan variabel kerjasama, 
motivasi, dan sikap dengan kinerja bidan dalam pelayanan antenatal baik pada pasien BPJS maupun pasien umum.

\section{HASIL DAN PEMBAHASAN}

\section{Kerjasama}

Hasil penelitian menunjukkan bahwa sebagian besar bidan bekerjasama dengan dokter pembina $(61,1 \%)$ dan PPK I (80,6\%). Tidak ada bidan yang bekerjama langsung dengan BPJS karena di Kecamatan Kejayan telah terdapat 2 puskesmas dan 2 praktik dokter swasta. Sesuai dengan Permenkes Nomor 71 Tahun 2013 bidan tidak dapat bekerjasama langsung dengan BPJS kecuali dalam suatu wilayah tidak terdapat dokter. Diantara 29 bidan yang bekerjasama dengan PPK I hanya sebagian diatara bidan yang bekerjasama dengan dokter pembina $(65,5 \%)$. Selain itu diantara 36 bidan yang melakukan praktik hanya terdapat 27 bidan yang memiliki surat ijin praktik. Bidan yang belum memiliki surat ijin praktik merupakan bidan yang baru lulus dari akademi kebidanan tetapi telah bekerja sebagai bidan pembantu BPS atau bidan yang telah habis masa berlaku surat ijin praktiknya. Bidan seharusnya melakukan kerjasama dengan dokter pembina dan memiliki surat ijin praktik yang berlaku (Permenkes, 2013).

Bidan menyatakan bahwa mereka setuju mematuhi peraturan terkait JKN apabila melakukan kerjasama dengan PPK I maupun BPJS akan tetapi hanya $17(58,6 \%)$ bidan yang memiliki surat pernyataan mematuhi peraturan terkait JKN. Diantara 29 bidan yang bekerjasama dengan PPK I hanya $22(75,9 \%)$ bidan yang memiliki perjanjian tentang luas pelayanan yang diberikan, hanya 19 $(65,5 \%)$ bidan yang memiliki perjanjian besaran kapitasi, dan hanya 9 (31\%) bidan yang memiliki jumlah pasien yang bisa dilayani. Bidan yang tidak memiliki surat perjanjian merasa telah ada kesepakatan tertulis yang dimiliki oleh PPK I terkait luas pelayanan, besaran kapitasi. Sedangkan untuk jumlah pasien yang dilayani, tidak ada batasan perjajian secara tertulis. Bidan yang bekerjasama dengan PPK I seharusnya memiliki surat pernyataan mematuhi peraturan terkait JKN, surat perjanjian tentang luas pelayanan, kapitasi, dan jumlah pasien yang bisa dilayani (Permenkes, 2013).

\section{Motivasi}

Hasil penelitian menunjukkan bahwa sebagian besar $(83,3 \%)$ bidan memiliki motivasi yang tinggi untuk bekerjasama (dengan BPJS, PPK I, dan dokter pembina). Sebagian besar bidan merasa mendapatkan keuntungan apabila melakukan kerjasama dikarenakan banyak penduduk di Kecamatan Kejayan yang menjadi pasien jamkesmas. Peserta jamkesmas merupakan pasien BPJS. Besaran kapitasi dianggap telah sesuai, akan tetapi masih terdapat bidan yang kurang setuju dengan besaran kapitasi yang telah ditentukan. Persyaratan, prosedur, dan proses administrasi dalam bekerjasama dianggap mudah oleh sebagian besar bidan di Kecamatan Kejayan walaupun membutuhkan waktu cukup lama. Bidan merasa bahwa bekerjasama merupakan sebuah tanggung jawab profesi. Kerjasama juga dianggap sebagai pengembangan karir dan tantangan pekerjaan oleh sebagian besar bidan. 
Sikap

Hasil penelitian menunjukkan bahwa hampir semua $(94,4 \%)$ bidan memiliki sikap positif dengan adanya kerjasama. Berdasarkan hasil penelitian diketahui bahwa sebagian besar respon bidan terhadap adanya JKN merupakan respon positif. Respon positif tersebut timbul dikarenakan bidan menganggap bahwa adanya JKN dapat membuat ibu hamil memeriksakan kehamilan tanpa khawatir dengan besaran tarif pelayanan. Namun bidan kurang setuju apabila pasien BPJS hanya boleh dilayani oleh bidan yang bekerjasama dengan PPK I maupun BPJS.

Bidan memiliki respon positif terhadap persyaratan administrasi kapitasi dan laporan rutin. Bidan merasa bahwa sudah seharusnya bidan memenuhi persyaratan dan memberikan laporan apabila melakukan kerjasama. Bidan juga telah mengetahui bahwa penentuan kapitasi ditentukan oleh BPJS dan penentuan tersebut berdasarkan rekomendasi lembaga terkait seperti ikatan profesi maupun dinas kesehatan. Bidan juga setuju bahwa kerjasama dapat meningkatkan kualitas pelayanan yang diberikan olehnya.

\section{Kinerja}

Kinerja dalam penelitian ini merupakan sesuatu yang harus dilakukan oleh bidan terkait pelayanan antenatal kepada ibu hamil. Penilaian kinerja berdasarkan indikator yang terdapat pada standar pelayanan antenatal tahun 2007. Kinerja bidan tentang pelayanan antenatal dipisah menjadi dua berdasarkan status kepesertaan ibu hamil sebagai pasien BPJS. Hasil penelitian menunjukkan bahwa sebagian besar kinerja bidan dalam pelayanan antenatal pada pasien BPJS sangat tinggi (85,2\%). Hasil penelitian menunjukkan bahwa kinerja bidan dalam pelayanan antenatal kepada pasien umum sebagian besar $(91,7 \%)$ sangat tinggi dan tidak terdapat bidan yang memiliki kinerja yang rendah maupun sangat rendah.

Kinerja bidan dalam pelayanan antenatal dalam kategori sangat tinggi, akan tetapi terdapat peningkatan kematian ibu di Kecamatan Kejayan. Peningkatan kematian ibu dapat disebabkan oleh faktor lain seperti keterlambatan mendapat pelayanan persalinan, keterlambatan stabilisasi dan rujukan ketika terjadi kegawatdarutan, kinerja bidan dalam pelayanan persalinan dan nifas yang kurang baik. Berdasarkan data yang diperoleh dari dinas kesehatan pada saat penelitian, kematian ibu terjadi pada masa persalinan dan nifas. Kematian ibu yang terjadi pada masa persalainan dan nifas dapat menjadi indikator pelayanan kesehatan pada masa persalinan yang kurang baik. Kematian ibu pada saat bersalin dan nifas dapat menjadi salah satu indikator bahwa kinerja bidan dalam memberikan stabilisasi kurang baik selain itu kematian ibu dapat menjadi indikator bahwa bidan terlambat dalam melakukan rujukan.

\section{Hubungan Kerjasama dengan Kinerja}

Berdasarkan hasil penelitian diketahui bahwa tidak ada satupun bidan yang bekerjasama dengan BPJS sehingga tidak dapat dilakukan uji statistik antara variabel kerjasama (bidan dengan BPJS) dengan variabel kinerja bidan dalam pelayanan antenatal baik pada pasien BPJS maupun pada pasien umum. Bidan tidak bekerjasama langsung dengan BPJS karena telah tersedianya fasilitas 
Tabel 1 Tabulasi Silang antara Kerjasama, Motivasi, dan Sikap dengan Kinerja Bidan dalam Pelayanan Antenatal pada Pasien BPJS

\begin{tabular}{|c|c|c|c|c|c|}
\hline & \multicolumn{5}{|c|}{ Kinerja Bidan dalam Pelayanan Antenatal pada Pasien BPJS } \\
\hline & Sangat Rendah & Rendah & Sedang & Tinggi & Sangat Tinggi \\
\hline \multicolumn{6}{|l|}{ Kerja-sama } \\
\hline BPJS & $0 \%$ & $0 \%$ & $0 \%$ & $0 \%$ & $0 \%$ \\
\hline $\begin{array}{r}(-) \\
(+)\end{array}$ & $\begin{array}{l}0 \% \\
0 \%\end{array}$ & $\begin{array}{l}0 \% \\
0 \%\end{array}$ & $\begin{array}{l}7,4 \% \\
7,4 \%\end{array}$ & $\begin{array}{l}7,4 \% \\
7,4 \%\end{array}$ & $\begin{array}{l}85,2 \% \\
85,2 \%\end{array}$ \\
\hline $\begin{array}{r}\text { PPK I } \\
\\
\\
(-) \\
(+)\end{array}$ & $\begin{array}{l}0 \% \\
0 \%\end{array}$ & $\begin{array}{l}0 \% \\
0 \%\end{array}$ & $\begin{array}{c}0 \% \\
3,7 \%\end{array}$ & $\begin{array}{c}0 \% \\
3,7 \%\end{array}$ & $\begin{array}{c}0 \% \\
55,6 \%\end{array}$ \\
\hline & \multicolumn{4}{|c|}{ Dokter Pembina } & $29,6 \%$ \\
\hline \multicolumn{6}{|l|}{ Motivasi } \\
\hline Sangat Rendah & $0 \%$ & $0 \%$ & $0 \%$ & $0 \%$ & $0 \%$ \\
\hline Rendah & $0 \%$ & $0 \%$ & $0 \%$ & $0 \%$ & $0 \%$ \\
\hline Sedang & $0 \%$ & $0 \%$ & $0 \%$ & $0 \%$ & $3,7 \%$ \\
\hline Tinggi & $0 \%$ & $0 \%$ & $7,4 \%$ & $7,4 \%$ & $70,4 \%$ \\
\hline Sangat Tinggi & $0 \%$ & $0 \%$ & $0 \%$ & $0 \%$ & $11,1 \%$ \\
\hline \multicolumn{6}{|l|}{ Sikap } \\
\hline Respon Positif & $0 \%$ & $0 \%$ & $7,4 \%$ & $7,4 \%$ & $85,2 \%$ \\
\hline Respon Negatif & $0 \%$ & $0 \%$ & $0 \%$ & $0 \%$ & $0 \%$ \\
\hline
\end{tabular}

pelayanan kesehatan tingkat pertama di Kecamatan Kejayan. Fasilitas pelayanan kesehatan tingkat pertama di Kejayan terdiri atas dua puskesmas dan dua praktik dokter swasta.

Hubungan antara variabel kerjasama (bidan dengan PPK I) dengan kinerja bidan dalam pelayanan antenatal pada pasien BPJS tidak dapat dianalisis karena jawaban yang homogen. Hasil penelitian ini sudah sesuai dengan peraturan yang menunjukkan bahwa bidan dapat memberikan pelayanan antenatal hanya bidan yang telah menjalin kerjasama dengan BPJS atau PPK I kecuali dalam keadaan kegawatdaruratan.

Variabel kerjasama (bidan dengan PPK I) memiliki hubungan $(p=0,012)$ dengan kinerja bidan dalam pelayanan antenatal pada pasien umum. Namun uji statistik menunjukkan hubungan yang sedang $(r=0,446)$ antara variabel kerjasama (bidan dengan PPK I) dengan kinerja dalam pelayanan antenatal pada pasien umum. Penelitian ini sudah sesuai dengan teori yang menunjukkan bahwa kerjasama mempunyai hubungan yang kuat dengan kinerja. Ada hubungan antara kerjasama dengan dengan kinerja seseorang. Kerjasama memberikan pengaruh kepada kinerja. Kerjasama yang positif dapat meningkatkan kinerja seseorang sedangkan tidak adanya kerjasama maupun adanya kerjasama yang buruk dapat menurunkan kinerja seseorang (Puck and Pregernig, 2014). 
Tabel 2 Tabulasi Silang antara Kerjasama, Motivasi, dan Sikap dengan Kinerja Bidan dalam Pelayanan Antenatal pada Pasien Umum

\begin{tabular}{|c|c|c|c|c|c|}
\hline & \multicolumn{5}{|c|}{ Kinerja Bidan dalam Pelayanan Antenatal pada Pasien Umum } \\
\hline & Sangat Rendah & Rendah & Sedang & Tinggi & Sangat Tinggi \\
\hline \multicolumn{6}{|l|}{ Kerja-sama } \\
\hline BPJS & $0 \%$ & $0 \%$ & $0 \%$ & $0 \%$ & $0 \%$ \\
\hline $\begin{array}{r}(-) \\
(+)\end{array}$ & $\begin{array}{l}0 \% \\
0 \%\end{array}$ & $\begin{array}{l}0 \% \\
0 \%\end{array}$ & $\begin{array}{c}5,6 \% \\
0 \%\end{array}$ & $\begin{array}{l}2,8 \% \\
2,8 \%\end{array}$ & $\begin{array}{l}91,7 \% \\
77,8 \%\end{array}$ \\
\hline $\begin{array}{r}(-) \\
(+)\end{array}$ & $\begin{array}{l}0 \% \\
0 \%\end{array}$ & $\begin{array}{l}0 \% \\
0 \%\end{array}$ & $\begin{array}{c}5,6 \% \\
0 \%\end{array}$ & $\begin{array}{c}0 \% \\
2,8 \%\end{array}$ & $\begin{array}{l}13,9 \% \\
58,3 \%\end{array}$ \\
\hline & $0 \%$ & \multicolumn{4}{|c|}{ Dokter Pembina } \\
\hline \multicolumn{6}{|l|}{ Motivasi } \\
\hline Sangat Rendah & $0 \%$ & $0 \%$ & $0 \%$ & $0 \%$ & $0 \%$ \\
\hline Rendah & $0 \%$ & $0 \%$ & $5,6 \%$ & $0 \%$ & $0 \%$ \\
\hline Sedang & $0 \%$ & $0 \%$ & $0 \%$ & $0 \%$ & $2,8 \%$ \\
\hline Tinggi & $0 \%$ & $0 \%$ & $0 \%$ & $2,8 \%$ & $80,6 \%$ \\
\hline Sangat Tinggi & $0 \%$ & $0 \%$ & $0 \%$ & $0 \%$ & $8,3 \%$ \\
\hline \multicolumn{6}{|l|}{ Sikap } \\
\hline ResponPositif & $0 \%$ & $0 \%$ & $5,6 \%$ & $0 \%$ & $0 \%$ \\
\hline Respon Negatif & $0 \%$ & $0 \%$ & $0 \%$ & $2,8 \%$ & $91,7 \%$ \\
\hline
\end{tabular}

Kinerja secara kelompok atau grup tidak akan bagus jika kerjasamanya dibatasi meskipun seseorang mempunyai kinerja yang baik secara individual. Kelompok atau grup mempunyai kinerja baik dengan syarat pembagian tugas sesuai dan kerjasama dalam kelompok baik, meskipun terdapat salah satu seorang yang mempunyai kinerja kurang (Wickstrom, et al, 1998).

Hasil analisis statistik menunjukkan variabel kerjasama (bidan dengan dokter pembina) memiliki hubungan yang sangat lemah $(r=0,111)$ dengan variabel kinerja bidan dalam pelayanan antenatal pada pasien BPJS. Selain itu dari hasil uji statistik menunjukkan tidak ada hubungan $(p=0,844)$ antara variabel kerjasama (bidan dengan dokter pembina) dengan kinerja bidan dalam pelayanan antenatal pada pasien BPJS. Variabel kerjasama (bidan dengan dokter pembina) juga tidak ada hubungan $(p=0,145)$ dengan kinerja bidan dalam pelayanan antenatal pada pasien umum. Nilai uji statistik statistik koefisien kontingensi menunjukkan lemahnya hubungan $(r=0,311)$ variabel kerjasama (bidan dengan dokter pembina) dengan kinerja bidan dalam pelayanan antenatal pada pasien umum. 
Tabel 3 Signifikansi ( $p$ ) dan Kuat Hubungan ( $r$ ) Antara Kerjasama, Motivasi, dan Sikap dengan Kinerja Bidan dalam Pelayan Antenatal

\begin{tabular}{ccccccc}
\hline & & \multicolumn{2}{c}{ Kinerja Bidan pada Pasien } & \multicolumn{2}{c}{$\begin{array}{c}\text { Kinerja Bidan pada Pasien } \\
\text { UPJum }\end{array}$} \\
\cline { 3 - 6 } & & BPJS & r & p & r \\
\hline \multirow{3}{*}{ Kerja-sama } & BPJS & - & - & - & - \\
\cline { 2 - 6 } & PPK I & - & 0,111 & 0,145 & 0,311 \\
\cline { 2 - 6 } & Dokter Pembina & 0,844 & 0,068 & 0,001 & 0,521 \\
\hline & Motivasi & 0,668 & - & 0,001 & 0,707 \\
\hline
\end{tabular}

Hasil penelitian ini kurang sesuai dengan teori Gibson yang menunjukkan bahwa kerjasama mempunyai hubungan dengan kinerja, tetapi tidak semua kerjasama mempunyai efek yang sama dan tidak semua bentuk kerjasama memberikan keuntungan (Brito, et al, 2014).

Tidak adanya hubungan kerjasama (bidan dengan dokter pembina) dengan kinerja dalam pelayanan antenatal baik pada pasien BPJS maupun pada pasien umum dapat diketahui dari kinerja bidan yang sangat tinggi, baik yang bekerjasama dengan dokter pembina maupun tidak bekerjasama. Kinerja bidan yang tinggi meskipun tidak adanya hubungan kerjasama (bidan dengan dokter pembina) dapat disebabkan karena bidan telah memiliki pengetahuan, kemampuan, pengalaman, dan keterampilan yang cukup baik.

\section{Hubungan Motivasi dengan Kinerja}

Hasil analisis menunjukkan bahwa tidak ada hubungan $(p=0,668)$ antara motivasi dengan kinerja bidan dalam pelayanan antenatal pada pasien BPJS. selain itu hubungan antara variabel motivasi dengan kinerja dalam pelayanan antenatal pada pasien BPJS lemah $(r=0,086)$.

Hasil penelitian ini berbeda dengan teori Gibson yang menunjukkan bahwa ada hubungan antara motivasi dengan kinerja. Haron et al (2012) menyatakan ada pengaruh motivasi terhadap kinerja seseorang. Penyebab tidak adanya hubungan motivasi dengan kinerja dapat diakibatkan karena subjek telah memiliki kemampuan yang tinggi meskipun motivasinya rendah (Viljaranta, et al, 2009).

Sejalan dengan penelitian Viljantara, terdapat alasan tidak adanya hubungan antara motivasi dengan kinerja dalam pelayanan antenatal pada pasien BPJS. Tidak adanya hubungan variabel motivasi dengan kinerja dalam pelayanan antenatal pada pasien BPJS dalam penelitian ini dapat disebabkan karena adanya bidan yang tidak dapat memberikan pelayanan antenatal pada pasien BPJS meskipun memiliki motivasi yang tinggi untuk bekerjasama. Hasil wawancara dengan responden menunjukkan bahwa sebagian responden tidak dapat memberikan pelayanan terhadap pasien BPJS karena mereka belum bekerjasama dengan PPK I. Responden yang memiliki motivasi tinggi tapi belum bekerjasama dengan PPK I dikarenakan adanya alasan pribadi seperti pindah rumah, pindah wilayah praktik, dan kesibukan bidan yang melanjutkan kuliah, mengajar sebagai dosen di universitas tertentu atau sebagai ibu rumah tangga.

Variabel motivasi memiliki hubungan $(p=0,001)$ dengan kinerja bidan dalam pelayanan 
antenatal pada pasien umum. Bidan yang memiliki motivasi sangat tinggi, tinggi maupun sedang dapat memberikan pelayanan pada pasien umum. Nilai hubungan ini sedang $(r=0,521)$, penelitian ini sesuai dengan teori Gibson bahwa motivasi memiliki hubungan dengan kinerja. Motivasi intrinsik memberikan kontribusi kepada kinerja seseorang. Motivasi merupakan faktor penting yang berkontribusi dalam kinerja seseorang dengan kemampuan yang lemah. Seseorang dengan motivasi tinggi akan berusaha mengembangkan kemampuannya sedangkan seseorang dengan motivasi rendah dapat menjadi lebih tertekan dan dapat menjadi seseorang dengan kemampuan yang lebih rendah (Logan, et al, 2011). Minat atau motivasi memberikan efek positif dalam kinerja seseorang (Ratelsdorf, et al, 2011).

\section{Hubungan Sikap dengan Kinerja}

Hubungan antara sikap dengan kinerja bidan dalam pelayanan antenatal pada pasien BPJS tidak dapat dianalisis karena respon bidan yang memberikan pelayanan pada pasien BPJS yaitu homogen (respon positif). Penelitian ini berbeda dengan teori Gibson yang menunjukkan ada hubungan antara sikap dengan kinerja. Sikap yang positif memberikan efek yang positif terhadap kinerja (Ulug, et al, 2011).

Terdapat perbedaan antara hubungan sikap dengan kinerja bidan dalam pelayanan antenatal pada pasien BPJS, variabel sikap menunjukkan adanya hubungan $(p=0,001)$ dengan kinerja bidan dalam pelayanan antenatal pada pasien umum. Hubungan variabel sikap dengan kinerja bidan dalam pelayanan antenatal pada pasien umum adalah kuat $(r=0,707)$. Penelitian ini sudah sesuai dengan teori Gibson dan penelitian Ulug, penelitian ini juga sejalan dengan penelitian Abu Bakar et al (2014) yang menunjukkan ada hubungan antara sikap dengan kinerja.

\section{SIMPULAN}

Berdasarkan hasil penelitian, analisis data, dan pembahasan yang telah dilakukan maka dapat diambil kesimpulan bahwa variabel yang paling berhubungan dengan variabel kinerja bidan dalam pelayanan antenatal pada pasien BPJS adalah variabel motivasi meskipun nilai hubungannya lemah. Sedangkan variabel yang paling berhubungan dengan kinerja bidan dalam pelayanan antenatal pada pasien umum adalah variabel sikap, nilai hubungan tersebut adalah kuat.

\section{DAFTAR PUSTAKA}

Abu Bakar, K., Tarmizi, R. A., Mahyuddin, R., Elias, H., Su, L. W., \& Ayub, A. F. (2010). Relationships Between University Students' Achievement Motivation,. Procedia Social and Behavioral Sciences Journal, 4906-4910. Retrived from http://www.science direct.com/science/article/pii/S187704281000 8335. 19 Desember 2014.

As'ad, M. (2003). Psikologi Industri. Yogyakarta: Liberty.

Azwar, Saifuddin. (2000). Reliabilitas dan Validitas. Yogyakarta: Pustaka Belajar.

Brito, L. A., Brito, E. P., \& Hashiba, L. H. (2014). What Type of Cooperation with Suppliers and Customers Lead to Superior Performance? Journal of Busines, 952-959. Retrieved from http://www.sciencedirect. com/science/article/pii/S0148296313002804. 19 Desember 2014.

Depkes RI. (1993). Panduan Bidan di Tingkat Desa, Dirjend Binkesmas. Jakarta: Depkes RI.

Depkes RI. (2007). Pedoman Pelayanan Antenatal. Jakarta: Depkes RI.

Depkes RI. (2009). Pemantauan Wilayah Setempat (PWS) KIA. Jakarta: Depkes RI.

Dinkes Pasuruan. (2014). Laporan Kesehatan Ibu dan Anak Tahun 2011-2013. Pasuruan: Dinkes Pasuruan. 
Gibson, J. L., Ivancevich, J. M., \& Donnellly, J. H. (1989). Organisasi (Perilaku, Struktur, Proses). Jakarta: Erlangga.

Haron, H. N., Shaharoun, A. M., Puteh, M., \& Harun, H. (2012). Does Motivation Affect Students' Understanding And Performance In Engineering Statics? Social and Behavioral Sciences , 191-203. Retrieved from http://www.sciencedirect.com/science/ article/pii/S1877042812041080.19 Desember 2014.

llyas, Y. (2001). Kinerja, Teori, Penilaian dan Penelitian. Jakarta: Pusat Kajian Ekonomi Kesehatan Fakultas Kesehatan Masyarakat.

Logan, S., Medford, E., \& Hughes, N. (2011). The Importance of Intrinsic Motivation for High and Low Ability Readers' Reading. Learning and Individual Differences Journal, 124-128. Retrieved from http://www.research.ed.ac.uk/ portal/en/publications/the - importance - of intrinsic - motivation - for - high - and - low - ability - readers - reading - comprehension - performance\%286895aab8 - d43b - 41e7 b747-5939e60ca20c\%29.html. 19 Desember 2014.

Permenkes. (2007). Peraturan Menteri Kesehatan Nomor 369 Tentang Standar Profesi Bidan. Jakarta.

Permenkes. (2010). Peraturan Menteri Kesehatan Nomor 1464 Tentang Izin dan Penyelenggaraan Praktik Bidan. Jakarta: Permenkes RI.

Permenkes. (2012). Peraturan Menteri Kesehatan Nomor 001 Tentang Sistem Rujukan Pelayanan Kesehatan Perorangan. Jakarta.

Permenkes. (2013). Peraturan Menteri Kesehatan Nomor 71 Tentang Pelayanan Kesehatan pada JKN. Jakarta.

Perpres. (2013). Peraturan Presiden Nomor 12 Tentang Jaminan Kesehatan. Jakarta.

Puck, J., \& Pregernig, U. (2014). The Effect of Task Conflict and Cooperation On Performance of Teams. European Management Journal, 870-878. Retrieved from http://www. sciencedirect.com/science/article/pii/S026323 7314000437. 19 Desember 2014.
Purwoastuti, E., \& Walyani, E. S. (2014). Konsep Kebidanan. Yogyakarta: Pustaka Baru Press.

Ratelsdorf, J., Koller, O., \& Moller, J. (2011). On The Effects of Motivation On Reading Performance Growth In Secondary. Learning and Instruction Journal, 550-559. Retrieved from http://www.researchgate.net/publication/ 251624233_On_the_effects_of_motivation_o n_reading_performance_growth_in_secondar y_school. 19 Desember 2014.

Sofyan, M., Majid, N. A., \& Siahaan, R. (2006). Bidan Menyongsong Masa Depan. Jakarta: PP IBI.

Sugiono. (2002). Statistik untuk Penelitian. Bandung: Alfabeta.

Thabrany, Hasbullah. (2014). Jaminan Kesehatan Nasional. Depok: PT Raja Grafindo Persada.

Ulug, M., Ozden, M. S., \& Eryilmaz, A. (2011). The Effects of Teachers' Attitudes On Students' Personality and. Social and Behavioral Sciences Journal, 738-742. Retrieved from http://www.sciencedirect.com/science/article/ pii/S1877042811019690. 19 Desember 2014

Viljaranta, J., Lerkkanen, M. K., Poikkeus, A. M., Aunola, K., \& Nurmi, J. E. (2009). CrossLagged Relations Between Task Motivation and Performance. Learning and Instruction Journal, 335-344. Retrieved from http://www. researchgate.net/publication/223296417_Cro ss - lagged_relations_between_task motivation_and_performance_in_arithmetic and_literacy_in_kindergarten. 19 Desember $201 \overline{4}$.

Wickstrom, G., Hannus, L. H., Joki, M., \& Laine, M. (1998). Factors Related to Good Group Performance In Nursing. International Journal of Industrial Ergonomics , 327Đ331. Retrieved from http://www.sciencedirect. com/science/article/pii/S0169814197000851. 19 Desember 2014. 